\title{
Search for viral nucleic acid sequences in the post mortem brains of patients with schizophrenia and individuals who have committed suicide
}

\author{
G I CARTER, G R TAYLOR, T J CROW \\ From the Division of Psychiatry, Clinical Research Centre, Harrow, Middlesex, UK
}

SUMMARY Molecular hybridisation has been used to screen several areas of post mortem brain from 20 patients with schizophrenia, 23 individuals who were suspected of having committed suicide and 21 control cases, for viral nucleic acids. Cloned probes were able to detect picogram levels of viral DNA and to quantify herpes simplex type 1 DNA from encephalitic brain, but no sequences hybridising to cytomegalovirus, varicella zoster virus, herpes simplex type I or JC or BK papovaviruses were detected in any of the experimental samples. These findings are discussed with reference to the viral hypothesis of the aetiology of psychiatric disease.

Viral hypotheses of the aetiology of schizophrenia have been based on evidence from several sources, including reports of elevated antibodies to viruses in the serum and CSF from schizophrenic patients, ${ }^{1-3}$ and the association of schizophrenia-like symptoms with encephalitis lethargica. A "virus-like agent (VLA)" has been described in the CSF of a significant proportion of schizophrenic patients, ${ }^{45}$ and immunocytochemical localisation of viral antigens in schizophrenic post mortem brain has been reported. ${ }^{6}$ The neurotropic DNA viruses herpes simplex type 1 (HSV 1) and cytomegalovirus (CMV) are of particular interest. HSV 1 is able to establish latent infections in sensory ganglia, ${ }^{78}$ and studies on the distribution of HSV 1 (the commonest cause of encephalitis) in encephalitic brain ${ }^{9}$ have demonstrated an affinity for the temporal cortex and limbic system, where neuropathological abnormalities have been reported in schizophrenia. ${ }^{10}$ In addition an increased incidence of herpes virus antibodies has been reported in psychopathic disorder, ${ }^{11}$ and psychotic depression. ${ }^{12}$

The technique of molecular hybridisation has been reported to detect nucleic acid sequences homologous to HSV 1 in three of four brain smears from chronic psychiatric patients ${ }^{13}$ and in a separate study in six of 11 brain DNA extracts from patients with no clinical signs of herpesvirus infection. ${ }^{14}$ Hybridisation studies performed to date have failed to detect CMV

Address for reprint requests: Dr GR Taylor, Division of Psychiatry, Clinical Research Centre, Watford Rd, Harrow HAl 3UJ, UK.

Received 10 January and in revised form 2 July 1986. Accepted 3 July 1986 related nucleic acid in the hippocampus of the brains of six schizophrenics ${ }^{15}$ and in the temporal cortex of 25 schizophrenics. ${ }^{16}$ We present here an extension of these studies to screen DNA preparations from several areas of post mortem brain from 20 schizophrenics, 23 suicide cases and 21 non-neuropsychiatric controls for the nucleic acid sequences of the herpes viruses HSV 1, CMV and Varicella-zoster virus (VZV) and of the human polyoma virus $\mathrm{JC}(\mathrm{JCV})$, the aetiological agent of progressive multifocal leukoencephalopathy (PML), as well as a closely related papovavirus BK virus (BKV). JCV and BKV are ubiquitous human agents and as DNA viruses, should be well preserved post mortem. Hybridisation techniques for their detection have been described. ${ }^{17-19}$

\section{Materials and methods}

Plasmid pBR322 was obtained from Sigma. Plasmid pSG124, a pBR325 derivative containing a $21 \mathrm{kbp}$ insert of HSV 1 DNA was supplied by Dr RM Sandri-Goldin of the University of Michigan Medical School, USA. Plasmid pHIE2, consisting of pAT153 with a CMV Hind III F fragment ( $21 \mathrm{kbp})$ insert was supplied by Dr PJ Greenaway of the Central Public Health Laboratories, Porton Down, England. Dr AJ Davison of the Institute of Virology Glasgow, Scotland, supplied plasmid pVb, consisting of the b Kpn 1 VZV fragment $(18 \mathrm{kbp})^{20}$ cloned into pAT153, and Dr A Akrigg of the Central Public Health Laboratories supplied total genomic clones of JCV and BKV in plasmid pBR322.

Transformation of $E$. coli $\mathrm{HB} 101$ by the above plasmids with viral inserts was by the method of Lederberg and Cohen. ${ }^{21}$ Transformants were isolated by growth on LB 
agar (1.5\%) supplemented with appropriate antibiotics. Single colonies were grown up in $10 \mathrm{ml}$ then in $150 \mathrm{ml}$ broth cultures and amplified with chloramphenicol $(170 \mu \mathrm{g} / \mathrm{ml})$. Plasmid DNA was purified by the method of Birnboim. ${ }^{22}$

Post mortem brain material

All three series of brains were from the collection at the Division of Psychiatry, Clinical Research Centre, Harrow (see tables 1-4).

The control series of brains were collected from patients dying from a variety of causes in a District General Hospital without a known history of psychiatric or neurological disease. Patients with schizophrenia had died in one or other of two large mental hospitals. The diagnosis was established by application either of the St Louis criteria, or the Syndrome Checklist of the WHO Present State Examination, and in the majority of cases both. The brains of patients in the suicide series were collected with the cooperation of H.M. Coroner for Inner North London (Dr. D. R. Chambers). This series included three individuals who met DSM III criteria for major depression and in seven further cases evidence strongly suggested a past history of depression. Four individ-
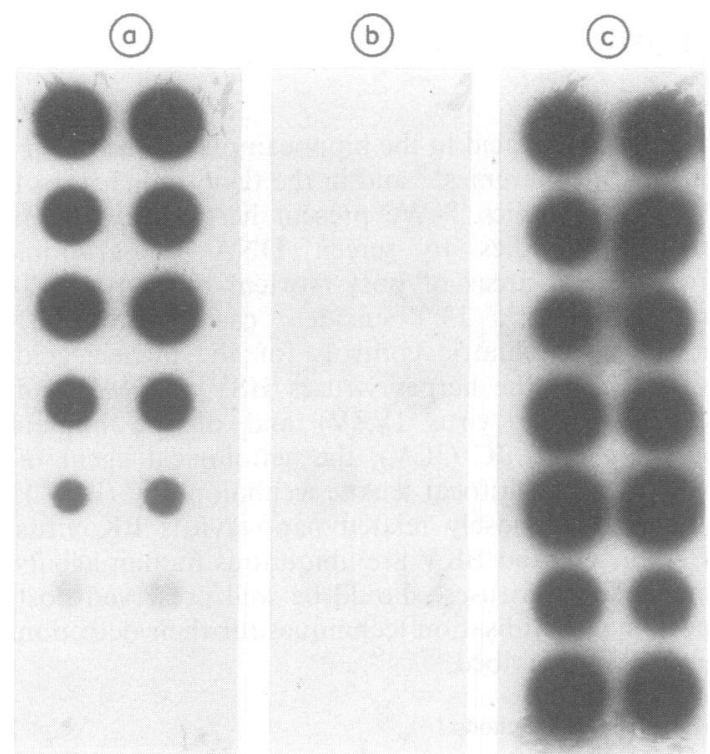

Fig (a) Detection of HSVI DVA in DNA prepared from temporal cortex of a case of herpes encephalitis. DNA was prepared as described in Materials and Methods. A duplicate set of serial 10 fold dilutions starting at $50 \mu \mathrm{g}$ DNA per spot was filtered. Cross hybridisation between $H S V-I$ sequences and the other probes used in this study was minimal apart from the HSVI Eco RIA clone, (b) Typical results of hybridisation of brain DNA extracts with serial probes. Hybridisation signals were not significantly above background as defined by signals from hybridisation with pBR322, (c) Hybridisation of brain DNA extracts with labelled human $D N A$, confirming the retention of denatured DNA by the filters. The amount retained was quantified by densitometry as described previously. ${ }^{23}$ uals were thought to have suffered from schizophrenia, two from personality disorder and in the remaining cases no diagnosis was possible.

Brains were dissected according to the standard procedures established at the Clinical Research Centre.

Table 1 Control series brains $n=21$, sex ratio $9 F: 12 M$, mean age $=53 \pm 15(S D)$ years.

\begin{tabular}{|c|c|c|c|c|}
\hline Number & $\begin{array}{l}\text { Age } \\
\text { (years) }\end{array}$ & Sex & Cause of death & $\begin{array}{l}\text { p.m. delay } \\
\text { (hours) }\end{array}$ \\
\hline $\begin{array}{l}1 \\
2\end{array}$ & $\begin{array}{l}26 \\
59\end{array}$ & $\begin{array}{l}\mathrm{F} \\
\mathrm{M}\end{array}$ & $\begin{array}{l}\text { Electrocution } \\
\text { Coronary artery } \\
\text { occlusion/atheroma }\end{array}$ & $\begin{array}{l}21 \\
42\end{array}$ \\
\hline 3 & 51 & $\mathbf{M}$ & $\begin{array}{l}\text { Coronary artery } \\
\text { occlusion/atheroma }\end{array}$ & 17 \\
\hline $\begin{array}{l}4 \\
5\end{array}$ & $\begin{array}{l}36 \\
57\end{array}$ & $\begin{array}{l}M \\
M\end{array}$ & $\begin{array}{l}\text { Coronary artery thrombosis } \\
\text { Not known }\end{array}$ & $\begin{array}{l}66 \\
72\end{array}$ \\
\hline 6 & 61 & M & $\begin{array}{l}\text { Coronary artery } \\
\text { occlusion/atheroma }\end{array}$ & 26 \\
\hline 7 & 65 & $\mathbf{M}$ & Coronary artery occlusion & 47 \\
\hline 8 & 51 & $\mathbf{M}$ & $\begin{array}{l}\text { Coronary artery } \\
\text { occlusion/atheroma }\end{array}$ & 27 \\
\hline 9 & 54 & $\mathbf{M}$ & Myocardial infarction & 72 \\
\hline 10 & 80 & $\mathrm{~F}$ & Carbon monoxide poisoning & 78 \\
\hline 11 & 30 & $\mathrm{~F}$ & Diabetic coma & 56 \\
\hline 12 & 36 & $\mathrm{~F}$ & Coronary artery occlusion & 36 \\
\hline 13 & 68 & $\mathrm{~F}$ & $\begin{array}{l}\text { Coronary artery } \\
\text { occlusion/atheroma }\end{array}$ & 33 \\
\hline 14 & 59 & $\mathrm{~F}$ & $\begin{array}{l}\text { Peritonitis/perforated } \\
\text { ulcer/infarction/atheroma }\end{array}$ & 72 \\
\hline 15 & 61 & $\mathbf{M}$ & Pulmonary embolism & 24 \\
\hline $\begin{array}{l}16 \\
17\end{array}$ & $\begin{array}{l}24 \\
61\end{array}$ & $\begin{array}{l}\mathbf{M} \\
\mathbf{F}\end{array}$ & $\begin{array}{l}\text { Accidental overdose } \\
\text { Acute peritonitis/perforated }\end{array}$ & $\begin{array}{l}24 \\
62\end{array}$ \\
\hline & 59 & $\mathbf{F}$ & $\begin{array}{l}\text { ulcer } \\
\text { Coronary occlusion }\end{array}$ & 38 \\
\hline 19 & 51 & M & Myocardial infarction & 24 \\
\hline 20 & 59 & M & Coronary artery & 27 \\
\hline 21 & 67 & $\mathbf{F}$ & $\begin{array}{l}\text { Occiusion/atheroma } \\
\text { Bronchial asthma }\end{array}$ & 36 \\
\hline
\end{tabular}

Table 2 Schizophrenic series brains. $n=20$, sex ratio $7 F: 13 M$, mean age $=65 \pm 17(S D)$ years.

\begin{tabular}{|c|c|c|c|c|}
\hline Number & $\begin{array}{l}\text { Age } \\
\text { (years) }\end{array}$ & Sex & Cause of death & $\begin{array}{l}\text { p.m. delay } \\
\text { (hours) }\end{array}$ \\
\hline $\begin{array}{l}22 \\
23\end{array}$ & $\begin{array}{l}61 \\
36\end{array}$ & $\begin{array}{l}\mathbf{M} \\
\mathbf{M}\end{array}$ & $\begin{array}{l}\text { Myocardial failure } \\
\text { Haemhorrage from acute } \\
\text { gastric ulcers }\end{array}$ & $\begin{array}{l}72 \\
72\end{array}$ \\
\hline 24 & 70 & $\mathbf{M}$ & Bronchial pneumonia & 76 \\
\hline 25 & 74 & $\mathbf{F}$ & $\begin{array}{l}\text { Bronchial pneumonia }+ \\
\text { ischaemic heart disease }\end{array}$ & 58 \\
\hline 26 & 76 & $\mathbf{M}$ & Bronchial pneumonia & 15 \\
\hline 27 & 76 & $\mathbf{M}$ & Bronchial pneumonia & 120 \\
\hline 28 & 83 & $F$ & Uraemia, peritonitis & 118 \\
\hline 29 & 74 & $\mathbf{F}$ & Haemhorrage & 47 \\
\hline 30 & 71 & $M$ & Coronary occlusion/atheroma & 48 \\
\hline 31 & 79 & $\mathbf{M}$ & Myocardial infarction & 52 \\
\hline 32 & 59 & M & Renal failure & 42 \\
\hline 33 & 40 & M & Obstruction & 69 \\
\hline 34 & 79 & $\mathbf{F}$ & Pulmonary oedema & 120 \\
\hline 35 & 84 & $\mathbf{F}$ & Bronchial pneumonia & 23 \\
\hline 36 & 50 & $\mathbf{F}$ & Uraemia, renal failure & 24 \\
\hline 37 & 69 & $\mathbf{M}$ & $\begin{array}{l}\text { Severe ischaemic heart } \\
\text { disease }\end{array}$ & 24 \\
\hline 38 & 69 & $\mathbf{M}$ & Intestinal obstruction & 20 \\
\hline 39 & 46 & $\mathrm{~F}$ & Bronchial pneumonia & 45 \\
\hline 40 & 79 & $\mathrm{M}$ & Cerebro-vascular accident & 24 \\
\hline 41 & 22 & $\mathbf{M}$ & Road traffic accident & 72 \\
\hline
\end{tabular}


Extraction and filtration of DNA

Extraction of DNA from $100 \pm 10 \mathrm{mg}$ brain tissue was as previously described, ${ }^{23}$ except that RNA was removed from total nucleic acid extracts by adding DNase inactivated RNase to a concentration of $1 \mathrm{mg} / \mathrm{ml}$ (total nucleic acids in $0.4 \mathrm{ml}$ STE buffer i.e. $100 \mathrm{mM} \mathrm{NaCl}, 10 \mathrm{mMTris}, 1 \mathrm{mM}$ EDTA, pH 8.0) and incubating at $30^{\circ} \mathrm{C}$ for 30 minutes with shaking. Size of extracted DNA was examined by agarose gel electrophoresis and DNA yields were determined spectrophotometrically, using the equation [DNA] $\mathrm{mg} / \mathrm{ml}=$ OD260 $\mathrm{nm} / 22$.

DNA samples were then denatured in a boiling water bath for 10 minutes, an equal volume of $20 \times \operatorname{SSC}$ buffer $(3 \mathrm{M}$ $\mathrm{NaCl}, 0.3 \mathrm{M}$ sodium citrate, $\mathrm{pH} 7 \cdot 0$ ) was added, and then $200 \mu \mathrm{l}$ aliquots $(5 \mu \mathrm{g})$ were filtered in duplicate through pre-

Table 3 Suicide series hrains. $n=23$, sex ratio $12 F: I I M$, mean age $=46 \pm 19(S D)$ years.

\begin{tabular}{|c|c|c|c|c|}
\hline Number & $\begin{array}{l}\text { Age } \\
\text { (years) }\end{array}$ & Sex & Cause of death & $\begin{array}{l}\text { p.m. delay } \\
\text { (hours) }\end{array}$ \\
\hline 42 & 21 & $F$ & Drug overdose & 69 \\
\hline 43 & 68 & $\mathrm{~F}$ & Fall & 24 \\
\hline 44 & 37 & $\mathbf{M}$ & Cardiac arrest/burns & 48 \\
\hline 45 & 74 & $M$ & Alcohol/drug overdose & 17 \\
\hline 46 & 61 & M & Fall & 48 \\
\hline 47 & 24 & $\mathbf{M}$ & Fall & 19 \\
\hline 48 & 36 & $\mathbf{M}$ & Hanging & 37 \\
\hline 49 & 33 & $\mathbf{M}$ & Alcohol/drug overdose & 24 \\
\hline 50 & 26 & $F$ & Struck by train & 64 \\
\hline 51 & 41 & $\mathrm{~F}$ & Drug overdose & 21 \\
\hline 52 & 27 & $\mathrm{~F}$ & Poisoning/drug overdose & 48 \\
\hline 53 & 71 & M & Drug overdose & 48 \\
\hline 54 & 24 & $\mathbf{M}$ & Drug overdose & 25 \\
\hline 55 & 73 & $\mathbf{M}$ & Drug overdose & 41 \\
\hline 56 & 48 & $\mathbf{M}$ & Drug overdose & 36 \\
\hline 57 & 63 & $\mathbf{F}$ & Drug overdose & 48 \\
\hline 58 & 22 & $\mathbf{M}$ & Hanging & 43 \\
\hline 59 & 70 & $\mathrm{~F}$ & Drowning & 24 \\
\hline 60 & 50 & $\mathrm{~F}$ & Drug overdose & 36 \\
\hline 61 & 65 & $\mathrm{~F}$ & Drug overdose & 24 \\
\hline 62 & 21 & $\mathrm{~F}$ & Alcohol/drug overdose & 48 \\
\hline 63 & 51 & $\mathrm{~F}$ & Drug overdose & 96 \\
\hline 64 & 57 & $\mathrm{~F}$ & Drug overdose & 72 \\
\hline
\end{tabular}

Table 4 Areas of control, schizophrenic and suicide post mortem hrains screened by molecular hybridisation.

\begin{tabular}{llll}
\hline Area & Controls & Schizophrenics & Suicides \\
\hline Caudate & 20 & 17 & 22 \\
Hippocampus & 17 & 14 & 18 \\
Putamen & 17 & 17 & 18 \\
Temporal cortex & 21 & 16 & 19 \\
Frontal cortex & 17 & 15 & 18 \\
\hline
\end{tabular}

wetted $(3 \times \mathrm{SSC})$ nitrocellulose membranes (Schleicher and Schuell) using a 96 well filtration manifold (BRL Ltd). After air drying and baking filters were stored at $-20^{\circ} \mathrm{C}$ in sealed bags until use.

\section{Molecular hybridisation}

Hybridisation and washing of filters was as previously described. ${ }^{23}$ Plasmids were labelled with deoxycytidine $5^{\prime}-\left[\alpha^{-32} \mathrm{P}\right]$ triphosphate (Amersham) by the nick translation method of Rigby $e^{2} \mathrm{al}^{24}$ to specific activities of the order of $3 \times 10^{8}-2 \times 10^{9} \mathrm{cpm} / \mu \mathrm{g}$ DNA. Human DNA was labelled to a specific activity of $1-2 \times 10^{6} \mathrm{cpm} / \mu \mathrm{g}$. Probes were used at a concentration of $10 \mathrm{ng} / \mathrm{ml}$, and the volume of hybridisation buffer: area of nitrocellulose ratio was maintained at $>0.1 \mathrm{ml} / \mathrm{cm}^{2}$. Hybridisation was at $65^{\circ} \mathrm{C}$ for 16 hours. After washing, filters were rinsed in $3 \times \mathrm{SSC}$ at room temperature, dried and exposed to Kodak X-Omat AR film, using Ilford Rapide intensifying screens at $-70^{\circ} \mathrm{C}$ for 1 to five days. Intensity of hybridisation was measured by densitometric scanning.

Filters were hybridised in sequence with labelled pBR322 (a control for non-specific hybridisation), pHIE2 (CMV), pSG124 (HSV), pVb (VZV), pJCV then pBKV. To determine assay sensitivity and ensure assay specificity control filters were included in each hybridisation. Controls for the pSG 124 hybridisation were of serial dilutions of pure HSV 1 DNA and of DNA extracted from the temporal cortex of a confirmed case of HSV 1 encephalitis and pH1E2 controls were serial dilutions of purified CMV DNA. For the $p V b$, $\mathrm{pJCV}$ and $\mathrm{pBKV}$ hybridisations fragments of viral nucleic acid were excised by restriction digestion, run on agarose gels, blotted onto nitrocellulose membranes by the method of Southern ${ }^{25}$ and hybridised to the appropriate ${ }^{32} \mathrm{P}$-labelled plasmid. Data presented in table 5 show assay sensitivity.

\section{Results}

DNA yields from frozen post mortem brain tissue were of the order of $0.45 \mathrm{mg} / \mathrm{g}$ wet wt tissue. Agarose gels $(1 \%)$ of the extracts stained with ethidium bromide and viewed under UV illumination showed preservation of fragment sizes greater than $20 \mathrm{~kb}$, suitable for dot blot hybridisation. RNA contamination was minimal.

Hybridisation signals between all the post mortem DNA preparations and labelled pBR322 were minimal. We did not observe any hybridisation between sample DNA and any of the viral probes which was above background but we were able to demonstrate

Table 5 Sensitivity of molecular hybridisation using viral probes, derived from dot blots (*) and from Southern blots of excised viral fragmients after agarose gel electrophoresis (†).

\begin{tabular}{|c|c|c|c|c|c|}
\hline Prohe' & lirus & Size of genome $(k h p)$ & $\begin{array}{l}\text { Fragment size } \\
(k h p)\end{array}$ & $\begin{array}{l}\text { Amount of homologous } \\
D N A \text { detectable (pg) }\end{array}$ & $\begin{array}{l}\text { Amount of viral } D N A \\
\text { detectable (pg) }\end{array}$ \\
\hline $\begin{array}{l}\text { pHIE2 } \\
\text { pVb } \\
\text { pSG124 } \\
\text { pJCV } \\
\text { pBKV }\end{array}$ & $\begin{array}{l}\text { CMV } \\
\text { VZV } \\
\text { HSV } \\
\text { JCV } \\
\text { BKV }\end{array}$ & $\begin{array}{l}225\left(1.5 \times 10^{6} \text { daltons }\right) \\
120\left(0.8 \times 10^{8} \text { daltons }\right) \\
150\left(1.0 \times 10^{8} \text { daltons }\right) \\
4.9\left(3.3 \times 10^{6} \text { daltons }\right) \\
5.2\left(3.5 \times 10^{6} \text { daltons }\right)\end{array}$ & $\begin{array}{l}21 \\
18 \\
21 \\
4 \cdot 9 \\
5 \cdot 2\end{array}$ & $\begin{array}{l}\overline{0.6 \dagger} \\
\overline{0.8 \dagger} \\
0.6 \dagger\end{array}$ & $\begin{array}{c}10 \cdot 7^{*} \\
4 \cdot 0^{*} \\
10 \cdot 0^{*} \\
0 \cdot 8^{\dagger} \\
0 \cdot 6^{\dagger}\end{array}$ \\
\hline
\end{tabular}


HSV1 DNA at a copy number of $1.38 \times 10^{3}$ copies/cell in a post mortem cortical sample of HSV1 temporal lobe encephalitis. Cross-reaction between viral probes and $\mathrm{pBR} 322$ was low and hybridisation to Southern blots of restriction fragments of CMV, VZV, JCV and BKV showed sensitivies of between $0.6 \mathrm{pg}$ and $10 \mathrm{pg}$ viral DNA.

\section{Discussion}

Molecular hybridisation utilising cloned viral probes is able to detect viral DNA sequences at picogram levels. The sensitive and specific assays used in this study were unable to detect viral sequences in the post mortem brains of control, schizophrenic or suicide cases, and hence our results are not in agreement with reports of the detection of HSV DNA in the brains of three of four chronic psychiatric patients, ${ }^{13}$ five of six epileptic patients, ${ }^{26}$ and in six of 11 control patients with no clinical signs of $\mathrm{HSV}$ infection. ${ }^{15}$ By incorporating cloned fragments of nucleic acid unique to viral genomes in our study we have minimised the possibility of cross hybridisation sometimes seen in hybridisations using whole genomic probes resulting from regions of homology between mammalian cell DNA and the genomes of herpes viruses, ${ }^{27}$ and by contamination of the probes with cellular sequences.

Our detection limits for HSV, CMV and VZV were $1.7 \times 10^{3}, 1.2 \times 10^{3}$ and $0.8 \times 10^{3}$ genome equivalents respectively. The amount of material filtered per sample onto nitrocellulose was $5 \mu \mathrm{g}\left(10^{6}\right.$ cells $)$ and hence the optimal detection limits in terms of genome equivalents/cell were 1 genome/588 cells for $\mathrm{HSV}$, 1 genome/833 cells for CMV and 1 genome/1250 cells for VZV, comparable with or better than those previously described with similar techniques. ${ }^{14152628-30}$ Assay sensitivity of the above limits would have allowed detection of viral genomes at the levels previously described in latent viral infections. Puga et al $^{8}$ have reported levels of $0 \cdot 11-0.30$ HSV DNA copies/cell in the trigeminal ganglia of mice chronically infected with HSV, and Cabrera et $\mathrm{al}^{28}$ have shown levels of HSV DNA of 0.01-0.05 copies/cell in the hemispheres and 0.22-1.78 copies/cell in the brain stem of mice with latent HSV. We were able to detect HSV sequences in the post mortem brain (temporal cortex) of a confirmed case of HSV encephalitis and demonstrate virus DNA at approximately $1 \times 10^{3}$ copies/cell demonstrating an active infection (Gilden et $\mathbf{l}^{31}$ reported VZV at a level of 700 copies/cell in infected cells).

In this study we report limits of detection of JCV and BKV of $0.8 \mathrm{pg}$ and $0.6 \mathrm{pg}$ respectively. This represents 1 genome/300 cells for JCV and 1 genome/350 cells for BKV. Our negative hybridisation results for these papovaviruses are in accordance with those reported by Chesters et al $^{32}$ who were unable to detect BKV or JCV in control or disease brain tissue (other than PML).

We conclude that our assay sensitivities should have been able to detect active infection (and probably viral latency) in the brain areas described, and although we cannot exclude a localised latent infection, or an infection in an area not examined in this study, our findings and those of Pogo and Elizan ${ }^{33}$ suggest that intracranial infection with these viruses is rare. Our findings suggest that these viruses are not systematically associated with either schizophrenia or types of affective illness which lead to suicide. The list of viruses surveyed is by no means exhaustive however, and serological evidence indicates that searches for other viruses should be undertaken. ${ }^{34}$

\section{References}

1 Albrecht P, Torrey EF, Boone E, Hicks JT, Daniel N Raised cytomegalovirus-antibody level in cerebrospinal fluid of schizophrenic patients. Lancet 1980;II:769.

2 Halonen PE, Rimon R, Arohonka K, Jantti V. Antibody levels to herpes simplex type 1 , measles and rubella viruses in psychiatric patients. $\mathrm{Br} J$ Psychiatry 1974; 125:461-5.

3 Torrey EF, Yolken RH, Winfrey CJ. Cytomegalovirus antibody in cerebrospinal fluid of schizophrenic patients detected by enzyme immunoassay. Science 1982;216:892-4.

4 Tyrrell DAJ, Parry RP, Crow TJ, Johnstone EC, Ferrier N. Possible virus in schizophrenia and some neuro-o logical disorders. Lancet 1979;I:839-41.

5 Crow TJ, Ferrier IN, Johnstone EC, et al. Characteristicse of patients with schizophrenia or neurological disorderand virus-like agent in cerebrospinal fluid. Lancet 1979;I:842-4.

6 Stevens JR, Albrecht P, Godfrey L, Krauthammer E. Viral antigen in the brain of schizophrenic patients? Adv Biol Psychiatry 1983;12:76-96.

7 Warren KG, Devlin M, Gilden DH, et al. Isolation of herpes simplex virus from human trigeminal ganglia, including ganglia from one patient with multiple sclerosis. Lancet 1977;11:637-9.

8 Puga A, Rosenthal JD, Openshaw H, Notkins AL. Herpes simplex virus DNA and mRNA sequences in acutely and chronically infected trigeminal ganglia of mice. Virology 1978;89:102-11.

9 Esiri MM. Herpes simplex encephalitis. An immunohistological study of the distribution of viral antigen within the brain. $J$ Neurol Sci 1982;54:209-26.

10 Brown R, Colter N, Corsellis JAN, et al. Post-mortem evidence for structural brain changes in schizophrenia. Arch Gen Psychiatry (in press).

11 Cleobury JF, Skinner GRB, Thouless ME, Wildy P. Association between psycopathic disorder and serum antibody to herpes simplex virus (type 1). Br Med J 1971;1:438-9.

12 Cappell R, Gregoire F, Thiry L, Sprecher S. Antibody and cell-mediated immunity to herpes simplex virus in 
psychotic depression. J Clin Psychiatry 1978;39:266-8.

13 Sequiera LW, Jennings LC, Carrasco LH, et al. Detection of herpes-simplex viral genome in brain tissue. Lancet 1979;II:609-12.

14 Fraser NW, Lawrence WC, Wroblewska Z, et al.Herpes simplex type 1 DNA in human brain tissue. Proc Natl Acad Sci USA 1981;78:6461-5.

15 Aulakh GS, Kleinman JE, Aulakh HS, et al. Search for cytomegalovirus in schizophrenic brain tissue. Proc Soc Exp Biol Med 1981;167:172-4.

16 Taylor GR, Crow TJ, Higgins T, Reynolds G. Search for cytomegalovirus in post mortem brain tissue from patients with Huntington's Chorea and other psychiatric disease by molecular hybridisation using cloned DNA. J Neuropath Exp Neurol 1981; 44:176-84.

17 Grinnell BW, Padgett BL, Walker DL. Distribution of non-integrated DNA from JC papovavirus in organs of patients with progressive multifocal leukoencephalopathy. J Infect Dis 1983;147:669-75.

18 Dörries K, ter Meulen V. Progressive multifocal leukoencephalopathy: detection of papovavirus JC in kidney tissue. J Med Virol 1983;11:307-17.

19 Arthur RR, Beckmann AM, Chi Li C, Saral R, Shah KV. Direct detection of human papovavirus BK in urine of bone marrow transplant recipients: comparison of DNA hybridization with ELISA. $J$ Med Virol 1985;16:29-36.

20 Davison AJ, Scott JE. Molecular cloning of the varicellazoster virus genome and derivation of six restriction endonuclease maps. J Gen Virol 1983;64:1811-14.

21 Lederberg EM, Cohen SN. Transformation of Salmonella typhomurium by plasmid deoxyribonucleic acid. J Bacteriol 1982;119:1072-4.

22 Birnboim HC. A rapid alkaline extraction method for the isolation of plasmid DNA. Methods Enzymol 1983;100:243-54.

23 Taylor GR, Crow TJ, Markakis DA, Lofthouse R, Neeley S, Carter GI. Herpes simplex virus and Alzheimer's disease: a search for virus DNA by spot hybridisation. J Neurol Neurosurg Psychiatry 1984; 47:1061-5.

24 Rigby PJW, Dieckmann M, Rhodes C, Berg P. Labelling deoxyribonucleic acid to high specific activity by in vitro nick translation with DNA polymerase $1 . \mathrm{J} \mathrm{Mol}$ Biol 1977:113:237-51.

25 Southern EM. Detection of specific sequences among DNA fragments separated by gel electrophoresis. J Mol Biol 1975;98:503-17.

26 Gannicliffe A, Saldanha JA, Itzhaki RF, Sutton RNP. Herpes simplex viral DNA in temporal lobe epilepsy. Lancet 1985;I:214-5.

27 Peden K, Mounts P, Hayward GS. Homology between mammalian cell DNA sequences and human herpes virus genomes detected by a hybridisation procedure with high-complexity probe. Cell 1982;31:71-80.

28 Cabrera CV, Wohlenberg C, Openshaw H, Rey-Mendez M, Puga A, Notkins AL. Herpes simplex virus DNA sequences in the CNS of latently infected mice. Nature 1980;288:288-90.

29 Seidlin M, Takiff HE, Smith HA, Hay J, Strauz SE. Detection of varicella-zoster virus by dot-blot hybridization using a molecularly cloned viral DNA probe. J Med Virol 1984;13:53-61.

30 Spector SA, Rua JA, Spector DH, McMillan R. Detection of human cytomegalovirus in clinical specimens by DNA-DNA hybridization. J Infect Dis 1984;150:121-6.

31 Gilden DH, Vafai A, Shtram Y, Becker Y, Devlin M, Wellish M. Varicella-zoster virus DNA in human sensory ganglia. Nature 1983;306:478-83.

32 Chesters PM, Heritage J, McCance DJ. Persistence of DNA sequences of BK virus and JC virus in normal human tissues and diseased tissues. $J$ Infect Dis 1983;147:676-84.

33 Pogo BGT, Elizan TS. Search for viral DNA sequences in Alzheimer brain tissue. Lancet 1985;1:978.

34 King DJ, Cooper SJ, Earle JAP, et al. A survey of serum antibodies to eight common viruses in psychiatric patients. Br J Psychiatry 1985;147:137-44. 